\title{
ANALISIS IMPLEMENTASI KEBIJAKAN PENINGKATAN KUALITAS TERHADAP PERMUKIMAN KUMUH (STUDI KASUS DI KECAMATAN TUNGKAL ILIR KABUPATEN TANJUNG JABUNG BARAT)
}

\begin{abstract}
Nuraida ${ }^{1}$ Tangerang Selatan, Indonesia idakualatungkal@gmail.com

Submitted: 11 Juli 2021 Revised: 1 December 2021 Accepted: 5 December 2021

\section{ABSTRACT}

This study aims to determine the conditions of housing and slum settlements inTungkal Ilir District, how to implement policies to improve the quality of slum housing and slum settlements in Tungkal Ilir District, what are the obstacles faced by the Government of West Tanjung Jabung Regency in implementing quality improvement of slum housing and slum settlements in Tungkal Ilir District. This study used a qualitative research method, with 19 informants who were selected using purposive sampling method. While the data analysis technique uses qualitative analysis with the stages of data reduction, data presentation, triangulation, drawing conclusions and verification. The results of this study indicate that the conditions of slum housing and slum settlements in Tungkal Ilir District are still classified as heavy slums, with an area of 138.11 hectares. The government has implemented policies well but overall it is not optimal, this can be seen from several variables such as Communication, Resources, Disposition and Bureaucracy. So that in its implementation there are obstacles in the form of budget limitations, lack of land and apathy from the community. The results of this study can be concluded that (1) the government will further increase its efforts in overcoming the existing slums (2) the government actually carries out the commitments that have been stated in the RPJMD of Tanjung Jabung Barat district, and (3) In improving the quality of slum housing and settlements slums are needed to strengthen synergy between related agencies and the community in consistent and periodic supervision so as not to cause new problems.
\end{abstract}

Keywords: implementation; policy; housing and slum areas

\section{ABSTRAK}

Penelitian ini bertujuan untuk mengetahui bagaimana kondisi perumahan dan permukiman kumuh di Kecamatan Tungkal Ilir, bagaimana implementasi kebijakan peningkatan kualitas perumahan kumuh dan permukiman kumuh di Kecamatan Tungkal Ilir, apa kendala yang dihadapi Pemerintah Kabupaten Tanjung Jabung Barat dalam implementasi peningkatan kualitas perumahan kumuh dan permukiman kumuh di Kecamatan Tungkal Ilir. Penelitian ini menggunakan metode penelitian kualitatif, dengan informan berjumlah 19 orang yang dipilih dengan menggunakan metode purposive sampling. Sedangkan teknik analisis data menggunakan analisis kualitatif dengan tahapan reduksi data, penyajian data, tringulasi, penarikan kesimpulan dan verifikasi. Hasil penelitian ini menunjukan bahwa kondisi Perumahan kumuh dan permukiman kumuh di Kecamatan tungkal Ilir masih tergolong kumuh berat, dengan luas 138.11 Ha. Pemerintah telah melakukan implementasi kebijakan dengan baik namun secara keseluruhan belum optimal, hal ini dapat dilihat dari beberapa variabel seperti Komunikasi, Sumber daya, Disposisi dan Birokrasi. Sehingga dalam pengimplementasiannya terdapat kendala berupa keterbatasan anggaran, kurangnya lahan dan sikap apatis dari masyarakat. Hasil penelitian ini dapat disimpulkan agar (1) Pemerintah lebih meningkatkan usaha dalam mengatasi kekumuhan yang ada (2) Pemerintah benar-benar menjalankan komitmen yang telah di tuangkan dalam RPJMD kabupaten Tanjung Jabung Barat, dan (3) Dalam peningkatan kualitas terhadap perumahan kumuh dan permukiman kumuh di perlukan adanya penguatan sinergi antar instansi terkait bersama masyarakat dalam pengawasan secara konsisten dan berkala agar tidak menimbulkan maslah baru.

Kata Kunci: implementasi; kebijakan; perumhan dan permukiman kumuh 
J1AD: Jurnal Ilmu Administrasi dan Pemerintahan Indonesia Volume 02 No 02 December 2021 Pages 111-119

\section{PENDAHULUAN}

Dunia telah mengalami peningkatan total yang luar biasa jumlah penduduk perkotaan, dari rata-rata tahunan 57 juta antara tahun 1990 dan 2000 hingga 77 juta antara tahun 2010 dan 2015 (Habitat, 2011) Oleh karena itu, populasi perkotaan dunia melonjak dari 2,3 miliar (43\% dari populasi dunia) pada tahun 1990 menjadi 4 miliar (54\% dari populasi dunia) pada tahun 2015. Perkiraan UN-Habitat menunjukkan bahwa satu di delapan orang (12,5\%) dari 7,6 miliar penduduk dunia saat ini bertempat tinggal di daerah kumuh.

Padahal persentase penduduk perkotaan dalam kondisi kumuh di negara berkembang telah menurun dari 46,2\% pada tahun 1990, 39,4\% pada tahun 2000, menjadi $32,6 \%$ pada tahun 2010 dan menjadi 29,7\% pada tahun 2014, mutlak jumlah penduduk kumuh telah meningkat dan akan terus berlanjut meningkat (Habitat, 2011). Perkiraan terbaru yang diberikan oleh UNHabitat menunjukkan bahwa jumlah penduduk perkotaan yang tinggal di daerah kumuh kondisi di negara berkembang lebih dari 880 juta pada tahun 2014, dari 791 juta pada tahun 2000, dan 689 juta pada tahun 1990.

Urbanisasi yang cepat dialami oleh seluruh wilayah di Indonesia, terutama didorong oleh peningkatan alami, migrasi pedesaan-perkotaan, pertumbuhan kota-kota besar yang membuat wilayah pemukiman kumuh semakin luas dan melahirkan pemukiman kumuh yang baru. Diperkirakan tahun 2030 populasi diperkotaan akan meningkat sebesar 2,9 miliar.(UN Habitat, 2018)

Dinegara berkembang, seperti Indonesia, tantangan Kawasan kumuh tetap ada, dan menjadi salah satu wajah kemiskinan, kekurangan, ketimpangan dalam wajah pemerintahan di Indonesia.

Orang yang tinggal dipermukiman kumuh, sering dianggap sebagai penyakit masyarakat, tidak dikenali oleh struktur pemerintahan, cenderung menghadapi diskriminasi dan kesulitan dalam menerima bantuan pemerintah yang ditujukan bagi masyarakat kurang mampu. Mereka tidak memiliki akses administrasi kependudukan yang aman. Mereka terus menerus hidup dibawah ancaman penggusuran, pengangguran atau memiliki pekerjaan yang beresiko, memiliki paparan yang tinggi terhadap penyakit dan kekeraan. Daerah Kumuh juga sering mengalami dampak yang ekstrim pada perubahan lingkungan. Untuk itu perlu colaboratif government untuk menyelesaikan masalah yang kompleks pada wilayah kumuh (Rulinawaty Kasmad, Samboteng, \& Mahsyar, 2019)

Wilayah pemukiman kumuh memiliki keterbatasan akses infrastruktur seperti fasiltas air, sanitasi dan limbah padat(Habitat, 2011). Perkiraan Program Pemantauan Bersama WHOUNICEF menunjukkan bahwa 844 juta dan 2,3 miliar orang secara global tidak memiliki akses ke

air minum dan sanitasi yang lebih baik masing-masing pada tahun 2015 (WHO/ UNICEF, 2017). Lebih lanjut disebutkan bahwa beberapa wilayah di Indonesia, daerah dengan proporsi terendah dari penduduk perkotaan dengan akses yang lebih baik terhadap sanitas, memiliki 225 juta penduduk perkotaan (60\% dari populasi perkotaannya) tidak memiliki akses ke sanitasi yang lebih baik pada tahun 2015 .

Rumah tinggal di kawasan kumuh di bawah standar dan tidak mematuhi menetapkan pedoman dan standar konstruksi. Tempat tinggal adalah sebagian besar dicirikan oleh struktur yang dibangun dengan lumpur, papan dan lembaran besi. UN Habitat (2018)menunjukkan bahwa 72\% dari semua bangunan kumuh di negara-negara yang menerapkan Participatory Slum Upgrading Program (PSUP) bersifat sementara.

Dunia telah membuat kemajuan dalam standar hidup jutaan orang penduduk perkotaan, termasuk rumah tangga dalam kondisi kumuh. Menurut Perserikatan Bangsa-Bangsa (2017), perbaikan telah disaksikan sejak Konferensinya tentang Pemukiman Manusia. Development Goals (MDGs) pada tahun 2000. Misalnya, antara tahun 2000 dan 2014, kehidupan 320 juta penghuni kawasan kumuh telah meningkat dibandingkan target MDG 7 kawasan kumuh (Target 7d) 100 juta orang pada tahun 2020 (UN Habitat, 2018)

Masyarakat internasional melalui agenda pembangunan global terus mengakui mengangkat kehidupan rumah tangga dalam kondisi kumuh sebagai salah satu strategi penting untuk memberantas kemiskinan secara global. Oleh karena itu, Agenda 2030 untuk Pembangunan Berkelanjutan seperti yang diungkapkan dalam Tujuan Pembangunan Berkelanjutan (SDGs) pada tahun 2030 untuk menyediakan fasili- 
Analisis Implementasi Kebijakan Peningkatan Kualitas terhadap Permukiman Kumuh

(Studi Kasus di Kecamatan Tungkal Ilir Kabupaten Tanjung Jabung Barat)

Nuraida

tas yang memadai, aman dan perumahan yang terjangkau dan layanan dasar untuk semua dan meningkatkan daerah kumuh (Halkos \& Gkampoura, 2021) Dan Agenda Baru Perkotaan (UNHabitat, 2016) yang bertujuan untuk berperan dalam pelaksanaan dan lokalisasi SDGs, sepakat untuk meningkatkan keuangan dan sumber daya manusia untuk peningkatan dan pencegahan permukiman kumuh daripada peningkatan fisik dan lingkungan untuk menjamin bahwa rumah tangga dalam kondisi kumuh dimasukkan ke dalam lingkungan sosial, ekonomi, budaya dan politik kota.

Pendekatan yang diadopsi termasuk akses ke perumahan, pelayanan dasar dan sosial yang berkelanjutan, memadai, aman, dan terjangkau. Pendekatan tersebut juga mencakup penyediaan ruang publik yang aman, inklusif, dapat diakses, hijau, dan berkualitas, serta berupaya memastikan kepemilikan keamanan dan pengaturannya. Namun, seperti bukti statistik tentang kejadian kumuh di negara berkembang, proporsi populasi kumuh di perkotaan tidak selalu sesuai dengan tren populsi daerah kumuh. Secara absolut, penduduk kumuh meningkat.

Peningkatan jumlah penghuni kawasan kumuh terus terjadi meskipun paya sejak tahun 1970-an oleh pemerintah nasional, badan pembangunan internasional dan organisasi masyarakat sipil (CBO) yang bekerja di kota-kota di seluruh dunia berkembang, termasuk Indonesia, untuk memastikan penyediaan fasilitas air dan sanitasi, peningkatan jalan, dan memastikan pembangunan unit hunian melalui strategi yang diakui sebagai perbaikan kawasan rumah kumuh.

Rumah merupakan kebutuhan dasar manusia dan mempunyai peran yang sangat strategis dalam membentuk watak serta kepribadian bangsa. Dalam rangka pemenuhan kebutuhan perumahan, pemerintah melakukan usaha-usaha pembangunan perumahan dengan melibatkan berbagai pihak baik perorangan maupun badan hukum. Usaha pemerintah tersebut tidak terlepas dari tujuan negara untuk menciptakan kesejahteraan bagi rakyatnya sebagaimana diamanatkan dalam Undang-Undang Dasar 1945 (UUD 1945).

Syamsiar,dkk, (2020) menjelaskan bahwa kota pada awalnya berupa permukiman dengan skala kecil, kemudian mengalami perkembangan sebagai akibat dari pertumbuhan penduduk, perubahan sosial ekonomi, dan budaya serta interaksinya dengan kota-kota lain dan daerah sekitarnya. Namun yang terjadi dengan kotakota di indonesia adalah bahwa pertumbuhan penduduk tidak diimbangi dengan pembangunan sarana dan prasarana kota dan peningkatan pelayanan perkotaan bahkan yang terjadi justru sebagai kawasan perkotaan mengalami degradasi lingkungan yang berpotensi menciptakan permukiman kumuh.

Seiring dengan pertumbuhan penduduk di daerah perkotaan, maka kebutuhan penyediaan akan prasarana dan sarana permukiman akan meningkat pula, baik melalui peningkatan maupun pembangunan baru sehingga kemampuan untuk membangun perumahan yang layak serta semakin terbatasnya lahan perkotaan untuk membangun permukiman yang mencukupi dan memenuhi syarat. Selanjutnya, pemenuhan akan kebutuhan prasarana dan sarana permukiman baik dari segi perumahan maupun lingkungan permukiman yang terjangkau dan layak huni belum sepenuhnya dapat disediakan baik oleh masyarakat sendiri maupun pemerintah, sehingga kapasitas daya dukung prasarana dan sarana lingkungan permukiman yang ada mulai menurun yang pada gilirannya memberikan kontribusi terjadinya lingkungan permukiman kumuh. Akibat makin banyaknya permukiman kumuh dan liar yang pada gilirannya akan menjadi berat bagi pemerintah kota untuk menanganinya permukiman kumuh merupakan salah satu masalah sosial di Indonesia yang tidak mudah untuk diatasi, sehingga pemerintah telah melakukan berbagai upaya dan program untuk mengatasinya. Sebagaimana yang telah diamanatkan dalam Undang-Undang Nomor 1 tahun 2011, tentang pembangunan perumahan dan permukiman, bahwa upaya penanganan permukiman kumuh harus memuat unsur-unsur pencegahan dan peningkatan kualitas permukiman kumuh yang di terjemahkan dalam bentuk strategi, program, dan rencana aksi kegiatan sesuai dengan ketentuan yang diamanatkan dalam Permen PUPR No. 02 tahun 2016 tentang peningkatan kualitas terhadap perumahan kumuh dan permukiman kumuh. Peningkatan kualitas terhadap perumahan kumuh dan permukiman kumuh adalah upaya untuk meningkatkan kualitas bangunan, serta perasarana, sarana dan utilitas umum.

Kota Kuala Tungkal merupakan salah satu 
Kota yang ada di Provinsi Jambi juga tidak lepas dari permasalahan permukiman kumuh, dalam laporan akhir Dinas Perumahan dan Kawasan Permukiman Kabupaten Tanjung Jabung Barat tahun 2017 tentang pendataan rumah di bantaran sungai Kota Kuala Tungkal. Secara umum kondisi permukiman dan perdesaan Kecamatan Tungkal Ilir sebagian besar berada di sekitar Sungai Pengabuan, permukiman perkotaan mengelompok di pusat dan sekitar Kota Kuala Tungkal dan sepanjang jalan linier yang ada di wilayah kota. Permukiman kumuh di Kota Kuala Tungkal kondisinya sangat memperihatinkan dan membutuhkan refitalisasi.

Lokasi Kawasan Kumuh yang ada di Kota Kuala Tungkal terdapat pada tiga kecamatan dan Sembilan kelurhan, sesuai dengan SK Bupati Tanjung Jabung Barat Nomor 438/Kep. Bup/BAPPEDA/2017 tentang penetapan lokasi Perumahan dan Permukiman Kumuh di Kabupaten Tanjung jabung Barat, bahwa tingkat kekumuhan yang terjadi merupakan kumuh berat sehingga harus mendapatkan perioritas penaganan yang tinggi.

\section{Perspektif Singkat Tentang Konsep Pena- taan Kawasan Kumuh.}

Definisi kerja UN-Habitat tentang daerah kumuh yang disepakati diskusi luas di antara para profesional dan organisasi pada tahun 2003, adalah umumnya digunakan di seluruh dunia. Definisi, yang didasarkan pada indikator terukur, menganggap perkampungan kumuh sebagai kawasan pemukiman yang memiliki setidaknya satu dari kondisi berikut: bangunan di bawah standar; kepadatan penduduk; akses yang buruk ke fasilitas sanitasi; dan status tempat tinggal yang tidak aman (Jain, 2010).

Aliansi Kota juga mendefinisikan daerah kumuh sebagai wilayah kotamadya yang terpinggirkan di mana standar hidup sangat buruk. Definisi menggambarkan daerah kumuh sebagai daerah yang memiliki kondisi kehidupan yang menyedihkan karena mereka cenderung tidak memiliki perumahan dasar, fasilitas umum, infrastruktur sosial dan ruang terbuka publik di dalam komunitas (Cities Alliance, 2013).

Berbeda dengan definisi UN-Habitat yang sangat didukung oleh pendekatan berbasis hak untuk pemenuhan hak atas akomodasi tempat tinggal yang dapat diterima di seluruh dunia, definisi oleh Aliansi Kota mengenali karakteristik khusus dari pemukiman. Namun, karakteristik utama yang diterima secara umum dalam semua definisi adalah bahwa kumuh adalah lingkungan yang dalam beberapa hal di bawah standar. Studi ini mengadopsi definisi kumuh seperti yang diberikan oleh Cities Alliance (2013).Definisi tersebut secara khusus mencakup masalah perumahan, air, sanitasi, pengumpulan sampah dan akses jalan yang menjadi fokusnya

belajar.

\section{Konseptualisasi Perbaikan Kawasan Ku- muh}

Menurut UN Habitat, (2018), perbaikan kawasan kumuh dalam arti sempit pandangan mengacu pada perbaikan perumahan dan/atau infrastruktur dasar di daerah kumuh. Dalam definisi yang lebih luas, peningkatan mencakup peningkatan

dalam proses ekonomi dan sosial yang dapat menghasilkan fisik seperti itu perbaikan. Dengan demikian, proyek dan program perbaikan kawasan kumuh berfokus tentang penyediaan layanan dasar untuk meningkatkan kesejahteraan masyarakat berpenghasilan rendah termasuk serangkaian intervensi infrastruktur yang sering dilakukan bersamaan dengan intervensi sosial, seperti regularisasi wilayah dengan implementasi yang tidak pasti(Mathur, 2008).

infrastruktur lainnya seperti perbaikan meliputi air, sanitasi, pengumpulan sampah, perumahan, akses jalan, jalan setapak, drainase badai, penerangan, telepon umum, sekolah, pos kesehatan dan pusat komunitas. Perbaikan sosial dapat termasuk penyediaan layanan kesehatan dan pendidikan yang lebih baik, pusat penitipan anak, pelatihan, dan program perlindungan sosial(Claude \& Claude, 2012).

Studi lain juga mengidentifikasi dan menguraikan indikator keberlanjutan untuk memasukkan perumahan, kesehatan, air minum, sistem pembuangan limbah dan keamanan (Uddin, 2018).

Cities Alliance, (2013) mengartikannya sedikit berbeda dengan mendefinisikan perumahan kumuh peningkatan sebagai perbaikan fisik, sosial, ekonomi, organisasi dan lingkungan dalam lingkungan yang mungkin dilakukan oleh warga negara, kelompok masyarakat, bisnis dan otoritas lokal dan nasional. Menurut Cities Alliance tindakan peningkatan kawasan kumuh 
Analisis Implementasi Kebijakan Peningkatan Kualitas terhadap Permukiman Kumuh (Studi Kasus di Kecamatan Tungkal Ilir Kabupaten Tanjung Jabung Barat)

Nuraida

yang khas mungkin melibatkan:

- Mengatur keamanan kepemilikan melalui pemetaan properti, sertifikasi

- dan pendaftaran;

- Memasang atau meningkatkan infrastruktur dasar, termasuk air, limbah

- pengumpulan, drainase badai, listrik, penerangan keamanan, dan publik

- telepon;

- Penghapusan atau mitigasi bahaya lingkungan;

- Memberikan insentif untuk pengelolaan dan pemeliharaan masyarakat;

- Membangun atau merehabilitasi fasilitas masyarakat seperti pembibitan, pos kesehatan, balai masyarakat;

- Perbaikan rumah, termasuk peningkatan material, konstruksi baru dan perluasan struktur yang ada;

- Relokasi/kompensasi bagi sejumlah kecil penduduk yang mengungsi akibat perbaikan;

- Meningkatkan akses ke perawatan kesehatan dan pendidikan serta sosial

- mendukung program untuk mengatasi masalah masyarakat seperti kejahatan dan

- penyalahgunaan zat;

- Peningkatan peluang mata pencaharian melalui pelatihan dan

- Pinjaman;

- Pengendalian kejahatan; dan

- Membangun modal sosial dan kerangka kelembagaan untuk mempertahankan

- perbaikan.

Untuk menciptakan infrastruktur dan SDM maka konsep agility dalam pemerintahan perlu dilakukan. Pemerintah yang gesit dan responsive dapat bekerja dengan cepat dalam menyelesaikan masalah-masalah yang kompleks. Masalah permukiman kumuh tidak akan bisa diselesaikan dengan pemerintah sebagai pemain tunggal, tetapi perlibatan pihak swasta dan masyarakat akan menghasilkan kinerja kebijakan yang dapat mengimplementasikan kebijakankebijakan pemerintah (Rulinawaty;, Samboteng;, Aripin;, \& Hasanuddin, 2020)

Berdasarkan uraian diatas penulis merasa perlu melakukan penelitian tentang Analisis Implementasi Kebijakan Peningkatan Kualitas Perumahan Kumuh Dan Permukiman Kumuh Di Kota Kuala Tungkal Kabupaten Tanjung Jabung Barat.

\section{METODE}

Penelitian yang dilakukan oleh penulis adalah dengan menggunakan metode penelitian kualitatif, dengan menggunakan data primer yang bersumber dari hasil wawancara dengan informan yang dipilih dengan methode purposive sampling, sedangkan data sekunder diperoleh dari dokumen-dokumen resmi yang digunakan seperti: hasil wawancara, catatan lapangan, foto, dokumentasi pribadi, catatan, atau memo dan dokumentasi lainnya.Teknik pengumpulan data yang digunakan dalam penelitian ini adalah teknik observasi, teknik wawancara dan teknik dokumentasi.

\section{HASIL DAN PEMBAHASAN}

\section{Bagaimana Kondisi Perumahan dan per- mukiman kumuh di Kecamatan Tugkal Ilir Kabupaten Tanjung Jabung Barat}

\section{Kondisi Fisik}

Kondisi fisik perumahan kumuh dan permukiman kumuh dapat dilihat dari tujuh indikator yaitu:

\section{Kodisi Bangunan}

Bahwa mayoritas bangunan rumah di kawasan kumuh Kecamatan Tungkal Ilir memiliki bangunan rumah yang tidak memenuhi standar teknis bangunan, dimana bangunan yang ada belum memiliki keteraturan bangunan, dan memiliki kepadatan bangunan yang tinggi.

\section{Kondisi Jalan Lingkungan}

Kondisi jalan lingkungan di daerah kawasan kumuh Kecamatan Tungkal Ilir masih terdapat beberapa jalan yang masih mengalami kerusakan dan perlu perbaikan, namun di sebagian jalan juga kondisinya sudah cukup baik.

\section{Ketersediaan Air Bersih/Air Minum}

Kondisi air minum yang ada di Kecamatan Tungkal Ilir belum ada ketersediaan air minum yang layak sehingga kebutuhan air minum belum bisa terpenuhi dengan baik, untuk memenuhi kebutuhan air minum masyarakat menggunakan air hujan dan air isi ulang.

\section{Kondisi Drainase Lingkungan}

Bahwa kondisi drainase yang ada di kecamatan tungkal ilir belum memadai, masalah 
drainase yang terjadi antar wilayah itu pada umumnya sama yakni drainase terbangun masih kurang, derainase yang sudah terbangun pun tidak terpelihara dengan baik sehingga tidak bisa mengalirkan limpasan air secara maksimal.

\section{Aspek Air Limbah}

Bahwa masyarakat disekitar masih membuang limbah rumah tangganya langsung ketanah dan sungai, dan sebagian sudah terhubung dengan septik tank namun juga masih banyak WC yang tidak permanen seperti jamban yang hanya terbuat dari papan saja yang kotorannya langsung jatuh kesungai sehingga di sekitar permukiman sering timbul bau yang tidak enak akibat dari pencemaran yang terjadi.

\section{Kondisi Persampahan}

Bahwa sebagian pembuangan sampah sudah terlayani oleh dari Dinas Lingkungan Hidup namun Prasarana dan sarana persampahan masih kurang, dan kurangnya kesadaran dari setiap masyarakat terhadap bahaya sampah, masih ada warga yang mebuang sampah sembarangan, tanpa peduli dari dampaknya, kemudian masih kurangnya sarana dan prasarana persampahan di setiap kelurahan.

\section{Proteksi Kebakaran}

Bahwa ketersediaan sarana dan prasarana pemadam kebakaran masih sangat minim, ketika terjadi bencana masyarakat benar-benar mengandalkan dari pihak damkar karna kondisi keberadaan prasana yang ada disetiap kelurahan ini belum cukup untuk mengatasi malasah ketika bencana kebakaran terjadi.

\section{Kondisi Ekonomi, Sosial Budaya}

\section{a. Kondisi Ekonomi}

kondisi ekonomi warga di Kawasan perumahan kumuh dan permukiman kumuh bahwa masyarakat sebagian besar untuk memenuhi kebutuhan ekonomi mereka memiliki pekerjaan yang beragam ada sebagai nelayan, tani, tukang ojek, pengolahan serta berjualan dan membuka usaha sendiri, adapun latar belakang pendidikan orang tua ada yang tamat SD, SMP dan SM namun bagi orang tua yang mampu anak- anak mereka sekarang sudah ada bisa sekolah sampai sarjana.

\section{b. Kondisi Sosial Budaya}

Bahwa kegiatan budaya masyarakat sudah hampir memudar, ini diakibatkan karna banyaknya pendatang sehingga masyarakat yang ada tidak bisa mempertahankan kebudayaan mereka, masyarakat yang datang tetap memakai kebudayaan mereka masing-masing, kebiasaan yang ada banyak yang telah dimodifikasi pelaksanaannya seperti acara pernikahan,namun dalam hal acara keagamaan masih tetap dipertahankan masih dilaksanakan secara rutin tiap tahunnya acara silaturrahmi masih terjalin dengan baik antar warga masyarakat namun saja untuk melakukan pertemuan rutin itu tidak bisa dilakukan lagi karna masing-masing warga sibuk dengan urusan masing masing-masing sehingga untuk mengumpulkan warga itu sudah sulit dilakukan.

\section{Implementasi Kebijakan peningkatan kualitas terhadap perumahan kumuh dan permukiman kumuh di Kecamatan Tugkal Ilir Kabupaten Tanjung Jabung Barat}

Implementasi kebijakan peningkatan $\mathrm{Ku}-$ alitas Perumahan kumuh dan permukiman kumuh di Kecamatan Tugkal ilir telah dilaksanakan sesuai dengan Permen PUPR No.02 tahun 2016 dan Perda Nomor 7 Tahun 2018 tentang Peningkatan kualitas terhadap perumahan kumuh dan permukiman kumuh di Kabupaten Tanjung Jabung Barat, hal ini dapat dilihat dari beberapa variable yaitu:

\section{Komunikasi}

Hasil wawancara dengan Cipto Hamonangan Siregar, S.Sos.MH Kepala Dinas Perumahan dan Kawasan Permmukiman pada tanggal (18/12/2019) terkait dengan komunikasi yaitu:

"bahwa kebijakan peningkatan kualitas perumahan kumuh dan permukiman kumuh di Kecamatan Tungkal Ilir Dinas Perumahan dan Kawasan Permukiman sebagai Implementatornya melakukan komunikasi dengan dinas terkait dengan cara melakukan rapat koordinasi rutin terkait dengan Peraturan Menteri PUPR Nomor 02 Tahun 2016 tentang peningkatan kualitas perumahan kumuh dan permukiman kumuh di Kecamatan Tungkal Ilir dan PERDA Nomor 7 Tahun 2018 tentang pencegahan dan peningkatan kualitas terhadap perumahan kumuh dan permukiman kumuh di Kecamatan Tungkal Ilir, selain itu kami juga sering melakukan komunikasi melalui media sosial”. 


\section{Sumber daya}

Variable kedua dalam implementasi kebiajakan peningkatan kualitas perumahan kumuh dan permukiman kumuh adalah Sumberdaya yang meliputi:

\section{a. Sumber daya manusia/staf,}

Hasil wawancara dengan Kristian, Kabid Kawasan Permukiman "bahwa untuk sumber daya manusia/staf pada Bidang Kawasan Permukiman dan Bidang Perumahan sebenarnya masih kurang namun kerja sama dan kesungguhan serta usaha yang dilakukan dapat menjalankan tugas dengan baik sesuai dengan apa yang diharapkan.

\section{b. Informasi}

Hasil Wawancara dengan Cipto Hamongan Siregar pada tanggal (18/12/2019) mengatakan:

"tentu kita menjalankan setiap kebijakan yang ada berdasarkan aturan yang telah dibuat, kalau terkait dengan peningkatan kualitas perumahan dan kawasan permikiman kan memang sudah ada di misi pembangunan Kabupaten Tanjung Jabung Barat terkait penuntasan kawasan kumuh itu, ada penanganan yang dilakukan secara bertahap pada lokasi yang telah ditetapkan perioritasnya, jadi kami dalam menjalankannya menjadikan itu sebagai dasar informasi ketika turun kelapangan".

\section{Sarana dan Prasarana}

Bahwa Dinas Perumahan dan Kawasan Permukiman telah memiliki fasilitas yang dapat digunakan sebagai penunjang berjalannya suatu kegiatan namun karena Dinas Perumahan dan Kawasan Permukiman ini masih bisa dikatakan baru dibentuk sehingga pengadaan fasilitas masih dilaksanakan secara bertahap namun dengan fasilitas yang ada sekarang sudah bisa membantu jalannya suatu pekerjaan dengan baik agar kebijakan dapat diimplementasikan dengan baik.

\section{Anggaran}

Hasil wawancara dengan Cipto Hamongan Siregar pada tanggal (18/12/2019) mengatakan:

"bahwa dari segi pendanaan dalam peningkatan kualitas perumhan kumuh dan permu- kiman kumuh di Kabupaten Tanjung Jabung Barat ini dibiayai oleh dana APBD dan APBN yang diharapkan dapat membantu jalannya proses suatu kebijakan, dengan luasan kumuh di Kecamatan Tungkal Ilir ini membutuhkan dana yang cukup banyak sehingga dana yang dianggarkan setiap tahunnya belum mampu menuntaskan kawasan kumuh meskipun telah dibantu dari dana APBN, selain itu dari segi dana di Kecamatan Tungkal Ilir dilaksanakan secara transparan".

\section{Disposisi}

Hasil wawancara dengan Cipto Hamonangan Siregar, S.Sos.MH sebagai Kepala Dinas Perumahan dan Kawasan Permmukiman pada (18/12/2019) menyebutkan:

\begin{abstract}
"bahwa pemerintah Daerah Kabupaten Tanjung Jabung Barat sekarang ini tengah fokus dalam penuntasan kawasan kumuh, memberikan perahatian dalam pelaksanaan programprogram yang ada dari pemerintah pusat, maupun dari Derah Kabupaten, Selain itu pemerintah juga telah memberikan komitmen pimpinan melalui Bupati yang dituangkan dalam dokumen RPJMD 2016-2021 bahwa peningkatan kualitas hidup masyarakat melalui penuntasan Kawasan Kumuh menjadi fokus capaian program pembangunan di Kabupaten Tanjung Jabung Barat”.
\end{abstract}

\section{Struktur Birokrasi}

Salah satu aspek struktur organisasi yang penting dari setiap adanya kebijakan adalah adanya Standar Oprasional Prosedur (SOP) yang bisa dijadikan pedoman bagi setiap implementator. keberadaan dinas Perumahan dan Kawasan Permukiman ini baru dibentuk yang merupakan pecahan dari Dinas PU namun demikian Dinas Perumahan dan Kawasan Permukiman sudah memiliki SOP tersendiri yang dijadikan pedoman dalam melaksanakan pekerjaan salah satunya dalam bidang peningkatan kualitas perumahan dan kawasan permukiman.

\section{Kendala yang dihadapi Pemerintah dalam Implementasi Kebijakan Pen- ingkatan Kualitas Perumahan Kumuh Dan Permukiman Kumuh di Kecamatan Tugkal Ilir}


J1AD: Jurnal Ilmu Administrasi dan Pemerintahan Indonesia Volume 02 No 02 December 2021 Pages 111-119

Dalam mengimplementasikan kebijakankebijakan Peningkatan Kualitas Perumahan Kumuh Dan Permukiman Kumuh di Kabupaten tanjung Jabung Barat Kecamatan Tugkal Ilir tentunya terdapat kendala yang dihadapi Pemerintah Kabupaten Tanjung Jabung Barat.

Hasil wawancara dengan Kepala dinas perumahan dan kawasan permukiman Cipto Hamonangan Siregar (18/12/2019) menyebutkan:

"yang menjadi kendala dalam Implementasi kebijakan peningkatan kualitas perumahan kumuh dan permukiman kumuh, yah kalau dari Pemerintah sendiri dapat berupa Keterbatasan Anggaran, Sumber Daya Manusia yang kurang, Kurangnya Lahan, dan kalau dari luar biasanaya sering ditemui dilapangan seperti sikap apatis dari masyarakat itu sendiri”.

\section{SIMPULAN DAN SARAN}

Berdasarkan hasil penelitian yang telah dilakukan oleh penulis maka dapat disimpulkan bahwa kondisi Perumahan kumuh dan permukiman kumuh di Kecamatan tungkal Ilir masih tergolong kumuh berat, dengan luas $138.11 \mathrm{Ha}$. Hal ini dapat dilihat dari kondisi fisik, yang dipengaruhi oleh 7 indikator kekumuhan yaitu: (1) Kondisi Bangunan gedung (2) Kondisi Jalan Lingkungan (3) Kondisi Air Bersih/air minum (4) Kondisi Drainase (5) Aspek Air Limbah (6) Kondisi Persampahan (7) Proteksi Kebakaran

Kemudian Implementasi Kebijakan yang dilaksanakan Dinas Perumahan dan Kawasan Permukiman sudah dilaksanakan namun belum optimal, hal ini dapat dilihat dari beberapa variabel implementasi kebijakan publik bahwa (1) Komunikasi berjalan dengan baik dengan dilakukannya rapat koordinasi dan sosialisasi dengan masyarakat, (2) Sumber daya staf yang dimiliki dapat bekerja dengan baik meskipun masih kurang kemudian sarana dan prasarana yang dimiliki sangat membantu dalam pelaksanaan kebijakan, Anggaran yang digunakan dalam pelaksanaan kebijakan berasal dari APBD dan APBN, (3) Disposisi sikap dan tanggung jawab dalam pelaksaan kebijakan dilaksanakan dengan baik hal ini dapat dilihat dari komitmen yang telah dituangkan dalam RPJMD, implementator telah mengimplementasikan kebijakan dengan dua pola penanganan yaitu: Pemugaran dan Permukiman Kembali, (3) Birokrasi bahwa implementator telah bekerja sesuai dengan tugas fungsi dan tanggung jawabnya menjalankan secara maksimal sesui dengan SOP dan dengan distribusi tugas dan fungsi pegawai.

Dalam mengimplementasikan seuatu kebijakan terdapat kendala dalam pelaksanaannya seperti keterbatasan anggaran, kurangnya lahan yang bisa digunakan untuk penataan perumahan kumuh dan permukiman kumuh dan sikap apatis dari masyarakat yang dapat menghambat pemerintah dalam melaksankan implementasi kebijakan terhadap peningkatan kualitas perumahan kumuh dan permukiman kumuh.

Berdasarkan kesimpulan diatas maka dapat disarankan kepada Pemerintah Daerah dalam peningkatan kualitas terhadap perumahan kumuh dan permukiman kumuh agar lebih meningkatkan usaha dalam mengatasi kekumuhan yang ada di Kecamatan Tungkal Ilir dengan memperhatikan 7 indikator kekumuhan agar bisa menguragi tingkat kekumuhan dan benarbenar menjalankan komitmen yang telah di tuangkan dalam RPJMD kabupaten Tanjung Jabung Barat dengan menyiapkan anggaran yang cukup dalam melakukan implementasi kebijakan, serta di perlukan adanya penguatan sinergi antar instansi terkait bersama masyarakat dalam pengawasan secara konsisten dan berkala agar tidak menimbulkan maslah baru.

\section{DAFTAR PUSTAKA}

Cities Alliance. (2013). Cities alliance for cities without slum: action plan for moving slum upgrading to scale. Special Summary Edition, 23.

Claude, M., \& Claude, M. (2012). Hybrid Modes of Organization. Alliances, Joint Ventures, Networks, and Other 'Strange' Animals To cite this version : Alliances , Joint Ventures , Networks , and other ' strange' animals . Claude Ménard University of Paris ( Pantheon-Sorbonne ) HAN.

Habitat, U. (2011). Forced evictions: Global crisis, global solutions.

Halkos, G., \& Gkampoura, E.-C. (2021). Reviewing the 17 Sustainable Development Goals : Importance and Progress. In Munich Personal RePEc Archive. Retrieved from https://mpra.ub.uni-muenchen.de/id/ eprint/105329

Jain, A. K. (2010). Inclusive Planning and Social Infrastructure. Bookwell.

Mathur, N. (2008). Urban Revitalisation and Participatory Governance: Methodology for a Discursive Policy Analysis. Policy and Society, 25(2), 77-108. https:// doi.org/10.1016/s1449-4035(06)70075-3

Rulinawaty;, Samboteng;, L., Aripin;, S., \& Hasanuddin. (2020). Crafting Agile Bureaucracy : Transforming Work Ethics of Civil Servants and Organisa- 
Analisis Implementasi Kebijakan Peningkatan Kualitas terhadap Permukiman Kumuh (Studi Kasus di Kecamatan Tungkal Ilir Kabupaten Tanjung Jabung Barat)

\section{Nuraida}

tional Culture of Bureaucracy in Indonesia. 12(11), 692-714.

Rulinawaty Kasmad, Samboteng, L., \& Mahsyar, A. (2019). The Unwise Policy Of Community Based-Organisation: Can It Empower Them? Implementation Network Of Food Diversification In Indonesia Rulinawaty. OPCION, 35(22), 2900-2961. https://doi. org/10.1017/CBO9781107415324.004

Syamsiar, N. R., Surya, B., \& Tato, S. (2020). Evaluasi Penanganan Permukiman Kumuh ( Studi Pada Penanganan Program Kotaku Kelurahan Banggae Kabupaten Majene ). 2(2), 54-65.

Uddin, N. (2018). Assessing urban sustainability of slum settlements in Bangladesh: Evidence from Chittagong city. Journal of Urban Management, 7(1), 32-42. https://doi.org/10.1016/j.jum.2018.03.002

UN-Habitat. (2016). Urbanization And Development Emerging Futures. In UN-Habitat (Vol. 21). https:// doi.org/10.1097/NCM.ooooooooooooo166

UN Habitat. (2018). Slum Almanac 2015/2016. Notes and Queries, s4-XII(308), 413-413. 